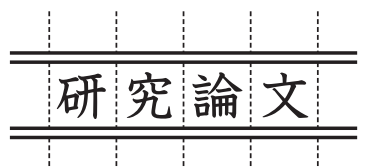

\title{
噴霧火炎操作条件が微小カーボン粒子の生成特性に及ぼす影響 \\ Effects of Operating Conditions of a Spray Flame on Characteristics of Carbon Fine Particle Formation
}

\author{
渡邊裕章*・黒瀬良一**・林＼cjkstart雅 人** $^{* *}$ \\ 北野智朗**・牧野尚夫*・小森 悟** \\ Hiroaki WATANABE, Ryoichi KUROSE, Masato HAYASHI, \\ Tomoaki KITANO, Hisao MAKINO and Satoru KOMORI
}

(Received June 22, 2012)

\begin{abstract}
A two-dimensional direct numerical simulation is applied to spray jet flames, and effects of background pressure and droplet size on soot formation behavior is investigated in detail in the mono-dispersed droplet size conditions. N-decane $\left(\mathrm{C}_{10} \mathrm{H}_{22}\right)$ is used as a liquid fuel, and droplet motion is calculated by the Lagrangian method. The extended flamelet/progress-variable approach is emplyed for the turbulent combustion chemistry. A kinetically based soot formation model with the flamelet model is employed to predict soot formation. The results show that the soot is mainly formed in the large vortex structure in the downstream region and the soot formation behavior is significantly affected by the pressure. It is found that the soot volume fraction and soot particle diameter increases with increasing the pressure due to that the concentration of soot precursor increases and the soot particles' residence time is enlongated in the structure.
\end{abstract}

Key Words: Numerical Simulation, Spray Flame, Soot Formation, Flamelet Model, Pressure

\section{1. 緒言}

噴霧燃焼は、液体燃料の主要な利用形態として、様々な 工業装置において利用されている。こうした工業装置で は、火炎中の多環芳香族炭化水素 $(\mathrm{PAH}$, Polycyclic Aromatic Hydrocarbon)の成長に伴って、すす等の微小なカーボン粒 子が生成されることが知られており、これが系外に排出さ れると大気污染の原因の一つとなると考えられている。ま た一方では、炭化水素然料の火炎中に生成される微小カー ボン粒子には、フラーレン等の高付加価值材料が含まれる ことが知られており、燃焼火炎の工業的利用として、こう した微小カーボン粒子製造が進められている。従って、環 境負荷低減に加え、機能材料の高付加価值化の点からも、 工学的観点から炭化水素然料の火炎中に生成される微小 カーボン粒子の生成メカニズムを解明し、その生成特性を 理解することは、極めて重要だと考えられる。しかしなが ら、噴霧火炎中では、液体燃料の微粒化、油滴の気相への 分散、蒸発、および燃料蒸気の空気との混合反応といった 多くの過程が同時に進行しながら起こるため、その火炎構 造は極めて複雑であり、依然不明な点が多い。これまで、
筆者らは、噴霧火炎の直接数值計算 (DNS, Direct Numerical Simulation)により、油滴の群燃焼や火炎片の挙動等につい て詳細な検討を行い、噴霧火炎の基礎的な燃焼特性につい て明らかにしてきた ${ }^{1 \sim 5)}$ 。

微小カーボン粒子の一種であるすすの生成挙動について は、近年、筆者らを含め、多くの研究者により精力的な研 究が進められている ${ }^{5 \sim 15)}$ 。この理由として、すす生成に係 わる化学種や微小すす粒子の挙動に関する数值モデルが提 案されるとともに、計算機性能の飛躍的発展に伴い、乱流 燃焼流の計算精度が向上していることが挙げられる ${ }^{16 \sim 18) 。 ~}$ 特に近年、詳細な化学反応を比較的低い計算負荷で考慮 可能な火炎片 (flamelet) モデル ${ }^{19,20)}$ が、実用規模の工業装 置への適用性の観点から注目されている。Flamelet モデル とは、素反応による詳細な反応計算の結果を、燃料ガスと 酸化剂の混合分率等をパラメータとして予めデータベース (flameletライブラリ) 化しておき、変動流れ場計算時には 適宜 flamelet ライブラリを参照することで、ガス温度や化 学種濃度を決定する手法である。Watanabe et al. は、燃料油 滴の当量比と輻射の影響の観点から、すすの生成挙動を、 112 化学種と 883 反応式を考慮した $n$-デカンの flamelet ラ

\footnotetext{
* 一般財団法人電力中央研究所 エネルギー技術研究所（％ 240-0196 神奈川県横須賀市長坂 2-6-1）

Energy Engineering Research Laboratory Central Research Institute of Electric Power Industry

(2-6-1 Nagasaka, Yokosuka, Kanagawa, 240-0196 Japan)

**京都大学大学院工学研究科 機械理工学専攻 ( $\overline{\mathrm{T}}$ 606-8501 京都府京都市左京区吉田本町)

Department of Mechanical Engineering \& Science, Kyoto University (Yoshida-honmachi, Sakyo-ku, Kyoto, 606-8501 Japan)
} 
イブラリを用いる flamelet モデルにより検討し、本手法に よって予測された噴霧火炎内のすす生成挙動が実験と定性 的に一致すること、および、すす生成が燃料油滴の当量比 や輻射伝熱に大きな影響を受けること等を明らかにした ${ }^{11}$ 。 また、Watanabe et al. は、Sauter 平均径 (SMD) が、拡散火 炎の形成とす寸生成に及ぼす影響を明らかにした ${ }^{22}$ 。さら に、Hayashi et al. は、単分散油滴径条件でのすす生成特性 について、詳細な実験と 2 次元 DNS を実施し、拡散火炎内 部から外部に向かってすす粒径が成長していく様子を明ら かにした ${ }^{13)}$ 。また、渡邊らは、ごく最近、より実用的な燃 焼場に近い噴流噴霧火炎中のすす生成挙動を明らかにして いる ${ }^{14)}$ 。しかしながら、多くの工業装置では加圧条件が多 く採用されている一方で、常圧よりも高い条件に打けるす す生成挙動については、ほとんど解明されていない。

そこで本研究では、噴流噴霧火炎を対象に 2 次元 DNS を 実施することにより、燃焼場の圧力がす寸生成や凝集過程 に及ぼす影響について明らかにすることを目的とする。す すの生成には、アセチレンを前駆体とした核生成、凝集、 表面成長、拉よび酸化反応の各過程を考慮する。

\section{2. 計算方法}

\section{1 支配方程式}

本研究では、速度論に基づくすす生成モデルを採用する。 すすの前駆体には $\mathrm{C}_{2} \mathrm{H}_{2}$ を、酸化剂には $\mathrm{OH}$ ラジカルと酸素 を考慮する。すす生成に関わるガス組成は、後述する拡張 flamelet/progress-variable 法により決定するが、燃焼反応に 伴う熱発生は、1 段総括反応により決定する。気相の支配 方程式は、質量、運動量、エネルギーおよび化学種質量分 率の各保存式である。

$\frac{\partial \rho}{\partial t}+\frac{\partial \rho u_{j}}{\partial x_{j}}=S_{\rho}$

$\frac{\partial \rho u_{i}}{\partial t}+\frac{\partial \rho u_{j} u_{i}}{\partial x_{j}}=-\frac{\partial p}{\partial x_{i}}+\frac{\partial \sigma_{i j}}{\partial x_{j}}+S_{u_{j}}$

$\frac{\partial \rho h}{\partial t}+\frac{\partial \rho u_{j} h}{\partial x_{j}}=\frac{\partial}{\partial x_{j}}\left(\rho a \frac{\partial h}{\partial x_{j}}\right)+S_{h}$

$\frac{\partial \rho Y_{k}}{\partial t}+\frac{\partial \rho u_{j} Y_{k}}{\partial x_{j}}=\frac{\partial}{\partial x_{j}}\left(\rho D_{k} \frac{\partial Y_{k}}{\partial x_{j}}\right)+S_{c o m b u, k}+S_{Y_{k}}$

ここで、 $\rho 、 u_{i} 、 h$ 掠よび $Y_{k}$ は、それぞれ密度、速度、全工 ンタルピ拉よび化学種質量分率である。また、 $\sigma_{i j}$ は粘性応 カテンソル、 $a$ は熱拡散係数、 $D_{k}$ は化学種の拡散係数である。 また、 $S$ は油滴との干渉による生成項であり、それぞれ次 式で表される。

$$
\begin{aligned}
& S_{\rho}=-\frac{1}{\Delta V} \sum_{N} \frac{d m_{d}}{d t} \\
& S_{u_{i}}=-\frac{1}{\Delta V} \sum_{N} \frac{d}{d t}\left(m_{d} u_{d, i}\right)
\end{aligned}
$$

$$
\begin{aligned}
& S_{h}=-\frac{1}{\Delta V} \sum_{N}\left[\frac{1}{2} \frac{d}{d t}\left(m_{d} u_{d, i} u_{d, i}\right)+Q_{d}+\frac{d}{d t}\left(c_{p, d} m_{d} T_{d}\right)\right] \\
& S_{Y_{k}}=-\frac{1}{\Delta V} \sum_{N} \frac{d m_{d}}{d t} \quad \text { (for fuel) }
\end{aligned}
$$$$
S_{Y_{k}}=0
$$$$
\text { (for other species) }
$$

$S_{c o m b u, k}=-\nu \frac{W_{k}}{W_{F}} R_{F}$

ここで、 $c_{p, d}$ は油滴比熱、 $\Delta V$ は検査体積、 $Q_{d}$ は対流熱流束 である。 $v$ は量論係数、 $W_{k}$ と $W_{F}$ はそれぞれの分子量、 $R_{F}$ は燃焼速度である。油滴の挙動は、ラグランジュ的に解く ことにより求める。油滴密度は気相よりも十分大きいと仮 定し、油滴の挙動に対して、抗力の影響のみを考虑し、流 れのせん断力に起因する揚力は無視する ${ }^{21)}$ 。さらに、油滴

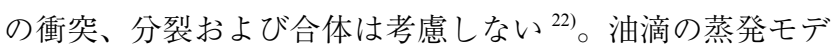
ルには、非平衡 Langmuir-Knudsen モデルを用いる ${ }^{23)}$ 。油滴 の位置 $\left(x_{d, i}\right)$ 、速度 $\left(u_{d, i}\right)$ 、温度 $\left(T_{d}\right)$ お よび質量 $\left(m_{d}\right)$ に関する 各保存式は、次式で表される。

$\frac{d x_{d, i}}{d t}=u_{d, i}$

$\frac{d u_{d, i}}{d t}=\frac{f_{1}}{\tau_{d}}\left(u_{i}-u_{d, i}\right)$

$\frac{d T_{d}}{d t}=\frac{\mathrm{Nu}}{3 \operatorname{Pr}}\left(\frac{c_{p}}{c_{p, d}}\right)\left(\frac{f_{2}}{\tau_{d}}\right)\left(T-T_{d}\right)+\frac{1}{m_{d}}\left(\frac{d m_{d}}{d t}\right) \frac{L_{V}}{c_{p, d}}$

$\frac{d m_{d}}{d t}=-\frac{\mathrm{Sh}}{3 \mathrm{Sc}} \frac{m_{d}}{\tau_{d}} \ln \left(1+B_{M}\right)$

ここで、 $L_{V}$ は潜熱、 $\mathrm{Nu} 、 \mathrm{Pr} 、 \mathrm{Sh}$ および Sc は、それぞれ Nusselt 数、Prandtl 数、Sherwood 数抢よび Schmidt 数、 $\tau_{d}$ は 粒子緩和時間、 $B_{M}$ は相間移動係数、 $f_{1}$ と $f_{2}$ はそれぞれ油滴 の蒸発による抗力と熱伝達に関する修正係数である ${ }^{24) 。 ~}$

以上の支配方程式㧍よび計算手法の詳細については、文 献 2〜4)を参照されたい。

\section{2 拡張 flamelet/progress-variable 法 ${ }^{25}$}

拡張 flamelet/progress-variable 法（FPVA-PE）では、デー タベースである flamelet ライブラリを参照しながら、変動 流れ場を計算することで、燃焼流に対する解を得る。本研 究では、Eqs.(1)〜 (4)の各保存式を解き、次の定義に従い、 混合分率 $(Z)$ と反応進行変数 $(C)$ を算出し、flameletライブ ラリを参照するものとする。

$Z=\frac{\nu Y_{F}-Y_{O}+Y_{O, 2}}{\nu Y_{F, 1}+Y_{O, 2}}$

$C=Y_{\mathrm{CO}_{2}}+Y_{\mathrm{H}_{2} \mathrm{O}}$

ここで、 $Y_{F, 1}$ と $Y_{O, 2}$ は、それぞれ燃料ガスと酸化剤の濃度 の境界条件である。次節にて述べるす寸生成に関わる化学 種は、 $Z$ と $C$ を参照パラメータとして、flameletライブラリ 
にテーブル化されている flamelet データを次式により抽出 する。

$$
Y_{k}=Y_{k}(Z, C)
$$

Flamelet ライブラリは、Z 空間において、1 次元火炎片方 程式を解くことで得られる。本研究では、 $Z$ 空間における $n$-デカン / 空気の 1 次元対向流拡散火炎方程式の計算に、 112 の化学種と 883 の素反応過程を考慮した ${ }^{26) 。 ~}$

\section{3 すす生成モデル}

本研究では、すすの挙動を、次に示すすすの数密度 $(N)$ と質量密度 $(M)$ の各保存式を解くことにより求める。

$\frac{\partial \rho \phi}{\partial t}+\frac{\partial}{\partial x_{j}}\left(\rho u_{j} \phi-\rho D_{s} \frac{\partial \phi}{\partial x_{j}}\right)=S_{\phi}$

ここで、 $D_{s}$ は拡散係数、 $\phi$ はまたは $M$ を表す。ただし、 $N$ と $M$ は次式で与えられる。

$N=N_{A} \rho \phi_{N}, \quad M=\rho \phi_{M}$

ここで、 $N_{A}$ はアボガドロ数である。また、それぞれの保存 式の生成項は、次式で表される。

$S_{N}=\frac{1}{N_{A}}\left[\left(\frac{d N}{d t}\right)_{\text {Inc. }}+\left(\frac{d N}{d t}\right)_{\mathrm{Coa} .}\right]$

$S_{N}=\frac{M_{P}}{N_{A}}\left(\frac{d N}{d t}\right)_{\text {Inc. }}+\left(\frac{d M}{d t}\right)_{\text {Gro. }}+\left(\frac{d M}{d t}\right)_{\text {Oxi. }}$

ここで、 $M_{P}$ はすすのモル質量である ${ }^{27)}$ 。本研究では、すす の生成は、核生成 (inception)、凝集 (coagulation)、表面成長 (surface growth)、および酸化反応 (oxidation) の各過程から 構成されるものと仮定する。

すすの前駆体として $\mathrm{C}_{2} \mathrm{H}_{2}$ を仮定し、すすの核生成速度に は、次式の Leung らのモデル 27) を用いる。

$\left(\frac{d N}{d t}\right)_{\text {Inc. }}=c_{1} N_{A}\left(\rho \frac{Y_{C_{2} H_{2}}}{W_{C_{2} H_{2}}}\right) e^{-\frac{E_{1}}{T}}$

ここで、 $c_{1}=54 \mathrm{~s}^{-1} 、 E_{1}=21100 \mathrm{~K}$ である ${ }^{7,27,28) 。}$

すすの凝集は、すす粒子同士の衝突頻度に比例すると考 えられる。衝突頻度は、すす粒径と周囲ガスの平均自由行 程から決められ、凝集速度は次式で与えられる ${ }^{29) 。 ~}$

$$
\begin{array}{r}
\left(\frac{d N}{d t}\right)_{\text {Coa. }}=-\left(\frac{24 R}{\rho_{\text {soot }} N_{A}}\right)^{1 / 2}\left(\frac{6}{\pi \rho_{\text {soot }}}\right)^{1 / 6} \\
\times T^{1 / 2} M^{1 / 6} N^{1 / 6}
\end{array}
$$

ここで、Rは一般ガス定数、 $\rho_{\text {soot }}$ はすすの密度である。

すすの表面成長は、核生成と同様に、 $\mathrm{C}_{2} \mathrm{H}_{2}$ が寄与する ものと仮定する。このとき、表面成長速度は次式で表され る $^{30,31)}$ 。

$$
\begin{aligned}
\left(\frac{d M}{d t}\right)_{\text {Gro. }} & =c_{4}\left(\rho \frac{Y_{C_{2} H_{2}}}{W_{C_{2} H_{2}}}\right) e^{-\frac{E_{2}}{T}} \\
\times & {\left[(\pi N)^{1 / 3}\left(\frac{6 M}{\rho_{\text {soot }}}\right)^{2 / 3}\right] }
\end{aligned}
$$

ここで、 $c_{4}=9000.6 \mathrm{~kg} \mathrm{~m} 、 E_{2}=12100 \mathrm{~K}$ である ${ }^{27,28)}$

$\mathrm{OH}$ ラジカルと酸素をすすの酸化剂として考慮する ${ }^{28,29)}$ 。 このときすすの酸化反応速度は、次式で表される。

$$
\begin{aligned}
\left(\frac{d M}{d t}\right)_{\text {oxi. }} & =-c_{5} \eta \rho \frac{Y_{O H}}{W_{O H}} T^{1 / 2}(\pi N)^{1 / 3}\left(\frac{6 M}{\rho_{\text {soot }}}\right)^{2 / 3} \\
& -c_{6} \rho \frac{Y_{O_{2}}}{W_{O_{2}}} e^{-\frac{E_{3}}{T}} T^{1 / 2}(\pi N)^{1 / 3}\left(\frac{6 M}{\rho_{\text {soot }}}\right)^{2 / 3}
\end{aligned}
$$

ここで、 $\eta=0.13 、 c_{5}=105.81 \mathrm{~kg} \mathrm{~m}$ および $c_{6}=8903.51 \mathrm{~kg} \mathrm{~m}$ 、 $E_{3}=19.778 \mathrm{~K}$ である ${ }^{32)}$

すす生成モデルに必要な化学種の濃度は、Eq.(15)により 決定される。

\section{4 計算条件}

Fig. 1 に計算領域と流入条件の概略を示す。噴霧油滴の 流入速度は、ガス流速と同様とした。計算領域は二次元の $0.0 \leqq x^{*} \leqq 4.5 、-1.0 \leqq y^{*} \leqq 1.0$ の矩形領域であり、計算格 子には、 $1500 \times 400$ 点を配置した。ただし、 $x^{*} と y^{*}$ は、基 準長さ $\left(L_{0}=5.0 \mathrm{~cm}\right)$ により無次元化した。格子は不等間隔 の直交スタッガード格子を使用した。スパン方向の空間刻 みは反応帯近傍で $\Delta y^{*}=0.0012$ 、主流方向の空間刻みは一定 で $\Delta x^{*}=0.003$ とした。また、流入境界以外は自由流出境界 とした。

運動量保存式の移流項には 2 次精度完全保存スキーム ${ }^{33)}$ を、スカラ量の移流項については QUICK スキーム ${ }^{34)}$ を用 いた。その他の項については 2 次精度中心差分を用いた。 計算のアルゴリズムは fractional step 法 ${ }^{35)}$ を用い、時間積分 は 2 次精度 Runge-Kutta 法を用いた。時間刻みは、クーラ ン数を 0.4 に固定して決定した。この時、時間刻みは $10^{-6} \mathrm{~s}$ オーダーとなる。

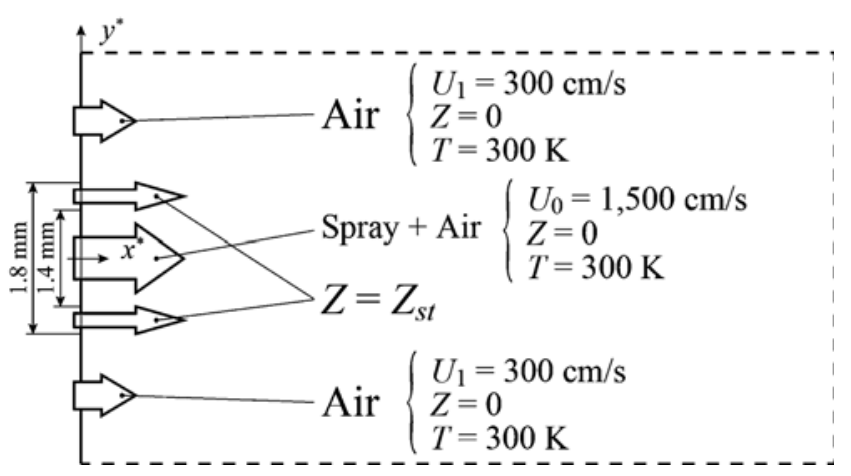

Fig. 1 Schemitics of computational setup 
噴霧火炎操作条件が微小カーボン粒子の生成特性に及ぼす影響（渡邊・黒瀬・林・北野・牧野・小森）

\begin{tabular}{c|c|c}
\multicolumn{3}{|c}{ Table 1 Cases presented } \\
\hline Cases & $\begin{array}{c}\text { Droplet size } \\
d_{p}(\mu \mathrm{m})\end{array}$ & $\begin{array}{c}\text { Pressure } \\
P(\mathrm{MPa})\end{array}$ \\
\hline Case 1A & 18 & 0.1 \\
Case 1B & 25 & 0.1 \\
Case 1C & 50 & 0.1 \\
\hline Case 2A & 18 & 0.2 \\
Case 2B & 25 & 0.2 \\
Case 2C & 50 & 0.2 \\
\hline Case 3A & 18 & 0.5 \\
Case 3B & 25 & 0.5 \\
Case 3C & 50 & 0.5 \\
\hline
\end{tabular}

本研究では、噴霧油滴の当量比 $\left(\phi_{l}\right)$ は、すべて 1.26 とし

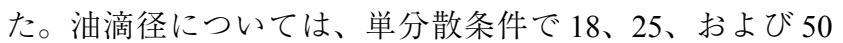
$\mu \mathrm{m}$ の計 3 条件を検討した。圧力については、0.1、0.2、お よび $0.5 \mathrm{MPa} の 3$ 条件を検討した。本研究で検討する条件 をTable 1 にまとめる。入口境界におけるガス流速の変動 は、文献 ${ }^{4)}$ と同様に考慮した。また、油滴の初期位置は一 様乱数を用いて決定し、その速度は気相の流入速度に等し いとした。

\section{3. 結果と考察}

\section{1 燃焼特性に対する圧力の影響}

Fig. 2 に、 $d_{p}=18 \mu \mathrm{m}$ 時の各圧力条件における (a) ガス温 度、および (b) 混合分率の瞬間分布を示す。図中 (a) の瞬間 ガス温度分布より、各条件において、燃料投入ポート直後 から、油滴噴流の上下外縁で着火し、下流に向かって火炎 が発達していることがわかる。Case 1Aに注目すると、 $x^{*}$ $=2.5$ 程度までの上流域では、安定した噴流火炎が形成され る一方で、 $x^{*}=2.5 \sim 3.0$ にかけて、噴流にともなう渦構造 が発達し、これにより下流域では火炎が分断され、独立し た渦状火炎が観察される。これらの噴流状火炎と渦状火炎 では、外縁部から中心部に向けて、次第に高温域が存在す ることがわかる。圧力の影響に着目すると、圧力が高くな るに従い、噴流にともなう渦構造が発達する位置が上流側 に移動するとともに、構造が微細化し、スパン方向に広が ることがわかる。これは、圧力の上昇とともに密度が高く なることで、Re 数が大きくなるためだと考えられる。他方、 図中 (b) の混合分率の瞬間分布は、ガス温度分布とよく似 た分布形状をもつ。これは、油滴の蒸発挙動に強い相関が あるためである。この混合分率の分布からも、圧力が高く なるに従い、上述の渦状火炎が微細化する様子や発達する 位置が上流側へ移動する様子を明確に確認できる。

Fig. 3 に $d_{p}=25 \mu \mathrm{m}$ 時、Fig. 4 に $d_{p}=50 \mu \mathrm{m}$ 時の各圧力 条件における (a) ガス温度、および (b) 混合分率の瞬間分布 をそれぞれ示す。各図のガス温度分布より、油滴径条件が $25 \mu \mathrm{m}$ および $50 \mu \mathrm{m}$ の場合においても Fig. 2 と同様に、噴

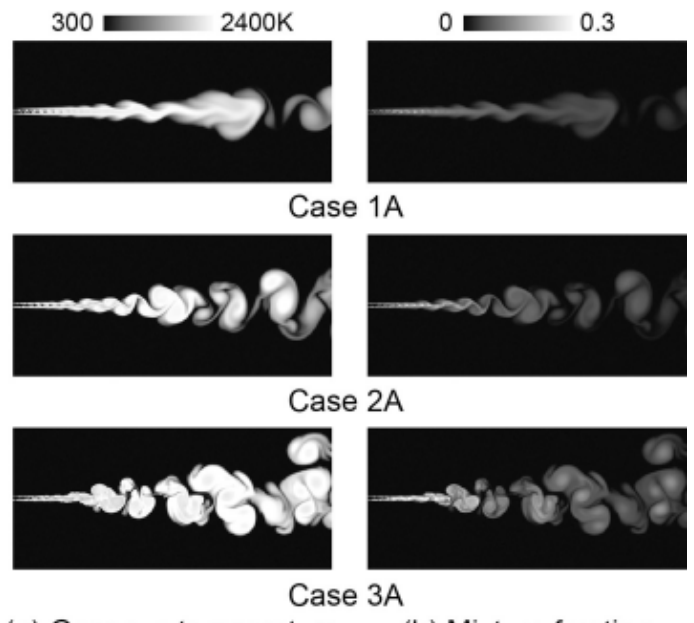

(a) Gaseous temperature

(b) Mixture fraction

Fig. 2 Instantaneous distributions of gaseous temperature and mixture fraction for $d_{p}=18 \mu \mathrm{m}$ with various pressure conditions.
$300=2400 \mathrm{~K}$

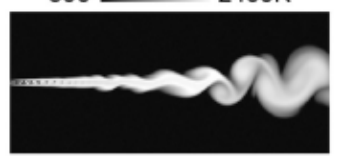

Case 1B

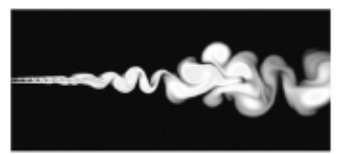

Case 2B

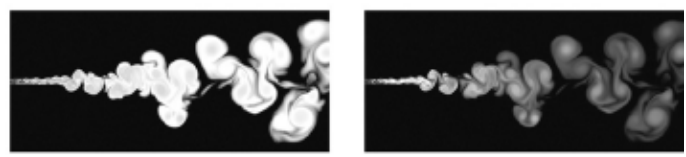

Case 3B

(a) Gaseous temperature

(b) Mixture fraction
Fig. 3 Instantaneous distributions of gaseous temperature and mixture fraction for $d_{p}=25 \mu \mathrm{m}$ with various pressure conditions.
$300=2400 \mathrm{~K}$

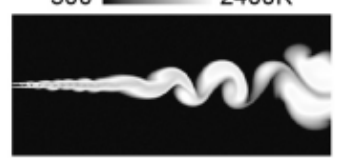

Case 1C
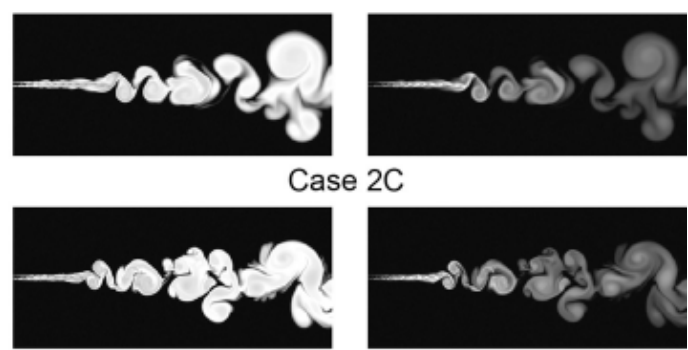

Case 3C

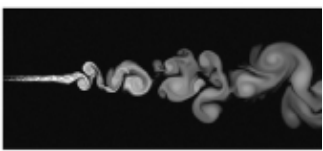

(b) Mixture fraction
Fig. 4 Instantaneous distributions of gaseous temperature and mixture fraction for $d_{p}=50 \mu \mathrm{m}$ with various pressure conditions. 

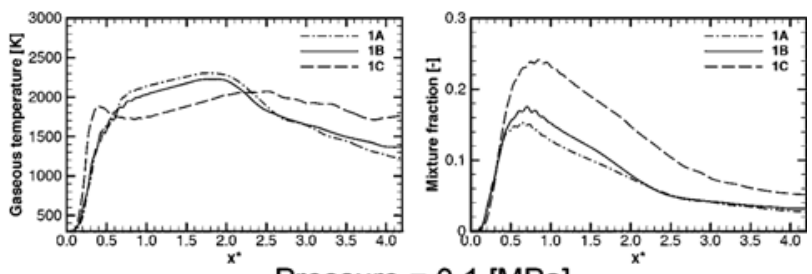

Pressure $=0.1[\mathrm{MPa}]$
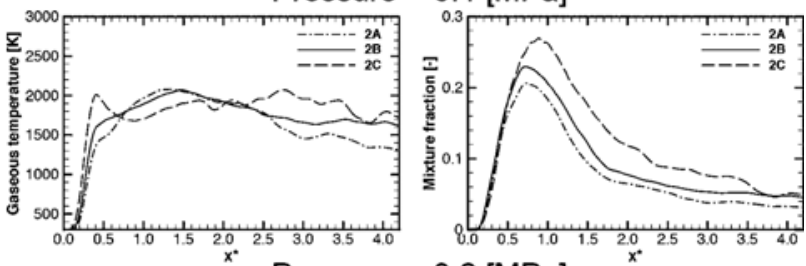

Pressure $=0.2[\mathrm{MPa}]$
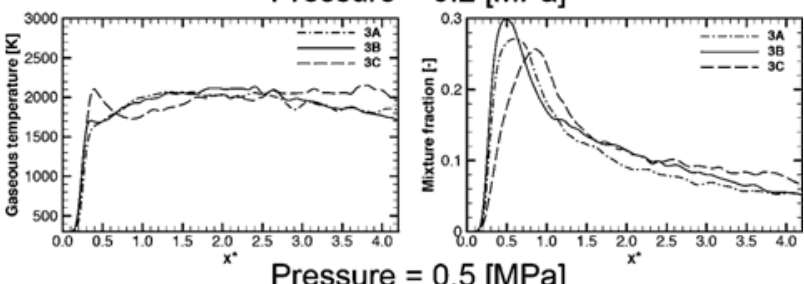

(a) Gaseous temperature

(b) Mixture fraction

Fig. 5 Axial distributions of time-averaged gaseous temperature and mixture fraction for various pressure and spray diameter.

流火炎の上流域に扔いて安定的な噴流状火炎が形成され、 その下流域に打いて大規模な渦状火炎が形成されること、 さらに、圧力の増加にともない、この洞状火炎が発達する 領域が上流域に移動すること等の挙動を観察することがで きる。油滴径の影響を調べるため、同一の圧力条件である Case 1A、Case 1B、拈よびCase 1C に注目すると、油滴径 が大きくなるに従い、噴流の下流域に形成される渦状火炎 がよりスパン方向に広がる傾向にあることがわかる。

Fig. 5 に、各油滴径、圧力条件におけるガス温度と混合 分率の中心軸上時間平均分布を示す。図より、0.1 MPa 時 には、油滴径が比較的小さい Case $1 \mathrm{~A}$ と Case $1 \mathrm{~B}$ は、 $x^{*}=0.2$ 〜 0.7 付近に扔いて、ガス温度が急激に上昇した後、 $x^{*}=$ 0.7 ～ 2.0 付近までさらになだらかに上昇し、その後、減少 する傾向にあり、両者はほぼ同様の分布形状となっている。 ただし、Case 1A のガス温度は Case 1B よりも、上流域にお いて高く、下流域に打いて低い值を示す。他方、最も油滴 径が大きいCase 1C は全く異なる挙動を示すことがわかる。 すなわち、ガス温度は、 $x^{*}=0.3$ 付近にピーク值が現れた後 に、一旦低下し、さらに $x^{*}=2.5$ 付近に向かって再び上昇 する傾向を示す。これは、蒸発速度が比較的遅い大きな油 滴が、火炎内部に取り残されて蒸発を続ける際の潜熱移動 に伴う cooling effectだと考えられる。ガス温度分布に対す る圧力の影響に注目すると、比較的小さな油滴径条件では、 燃料ポート直後に急激に昇温した後、さらになだらかな温 度上昇を示す傾向は同様に観察される一方で、ピーク值が

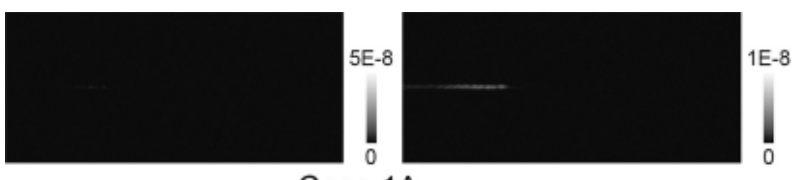

Case $1 \mathrm{~A}$
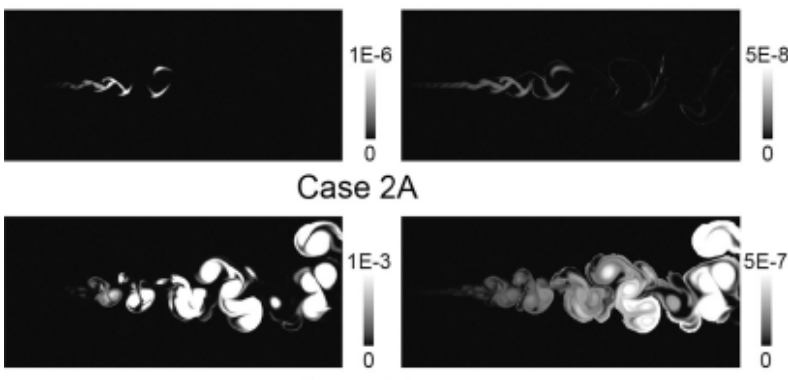

Case $3 A$

(a) Soot volume fraction

(b) Soot particle diameter

Fig. 6 Instantaneous distributions of soot volume fraction and soot particle diameter for $d_{p}=18 \mu \mathrm{m}$.

現れる位置が上流方向へ移動していることがわかる。また、 $d_{p}=50 \mu \mathrm{m}$ 時には、全ての条件において cooling effectが見 られる。一方、混合分率分布に注目すると、0.1 MPa 時に は、油滴径が大きくなるに従い、より高いピーク值をもつ こと、またピーク值が現れる位置が下流に移動することが わかる。これは、油滴径が大きいほど蒸発速度が遅いため、 燃料ガスのスパン方向への移流拡散が遅れることによる。 この傾向は、0.2MPa 時にも観察されるが、条件間の差異は 小さくなる。また、圧力が高くなるに従い、各油滴径条件 に㧍けるピーク值は、それぞれ大きくなるとともに、その 位置が上流方向へ移動すること、さらに分布形状はより急 峻なものになることがわかる。これは、より高い圧力にお いて、燃料油滴の沸点が上昇することで、飽和蒸気圧に至 るまでの油滴温度がより高温となるため、蒸発が促進され ることによると推察される ${ }^{36 。}$

\section{2 すす生成特性に対する圧力の影響}

Fig. 6 に、 $d_{p}=18 \mu \mathrm{m}$ 時の各圧力条件における (a)すす濃 度 (体積分率)、および (b) すす粒径の瞬間分布を示す。図 中 (a)のすす濃度分布より、0.1 MPa 時には $x^{*}=1.0$ 付近 に扔いてわずかに存在する程度であるのに対して、圧力が 上昇するに従い、すす濃度は劇的に高い值を示すことが わかる。また、す寸濃度が高い值を示すのは、0.1 MPa 時 は、噴流の上流域に存在する安定的な噴流状火炎内であり、 $0.2 \mathrm{MPa}$ 時は、 $x^{*}=1.0 \sim 2.0$ にかけて発達する渦の中心付 近、また $0.5 \mathrm{MPa}$ 時は、 $x^{*}=1.5$ 付近から下流に大きく発達 する渦状火炎内であり、圧力条件により異なることがわか る。また、図中 (b) すす粒径分布に注目すると、一般的に、 すす濃度が高い領域に扔いて、すす粒径も大きい傾向を示 すことがわかる。特に、下流域に発達する洞状火炎の中心 

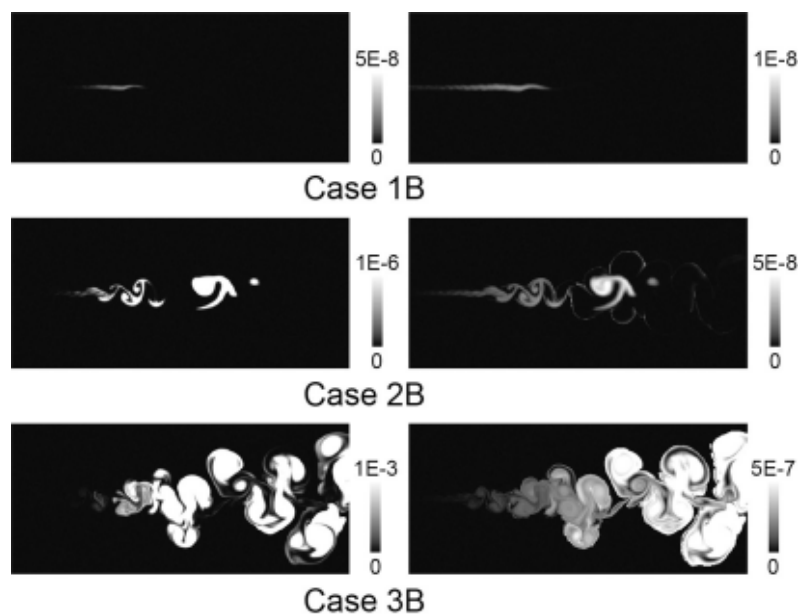

(a) Soot volume fraction

(b) Soot particle diameter

Fig. 7 Instantaneous distributions of soot volume fraction and soot particle diameter for $d_{p}=25 \mu \mathrm{m}$.
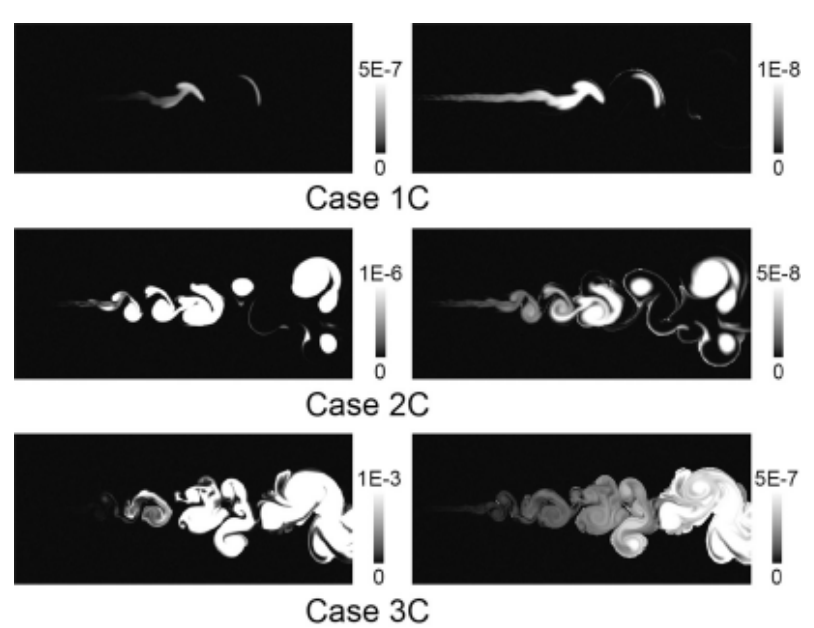

$\begin{array}{lll}\text { (a) Soot volume fraction } & \text { (b) Soot particle diameter }\end{array}$

Fig. 8 Instantaneous distributions of soot volume fraction and soot particle diameter for $d_{p}=50 \mu \mathrm{m}$.

部に向かって、すす濃度とす寸粒径は大きくなる傾向を示 すが、これは、渦状火炎の内部は高温かつ酸化剂不足の状 態にあり、上流域で生成されたすすの核粒子が、表面成長 反応や凝集により成長するための十分な滞留時間があるこ とによるものと思われる。

Fig. 7 に、 $d_{p}=25 \mu \mathrm{m}$ 時、Fig. 8 に $d_{p}=50 \mu \mathrm{m}$ 時の各圧力 条件に扔ける (a) すす濃度、打よび (b) すす粒径の瞬間分布 をそれぞれ示す。それぞれの図より、油滴径条件が $25 \mu \mathrm{m}$ 抄よび $50 \mu \mathrm{m}$ の場合に执いても Fig. 6 と同様に、圧力が高 くなるに従い、劇的にすす濃度が高い值を示すこと、渦状 火炎の発達に伴い、渦の中心に向かってすす濃度やすす粒 径は高い值を示すことがわかる。油滴径の影響に注目する と、油滴径が大きくなるほど、すす濃度とすす粒径はとも

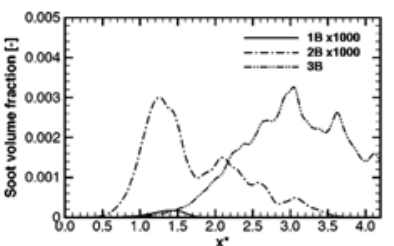

(a) Soot volume fraction

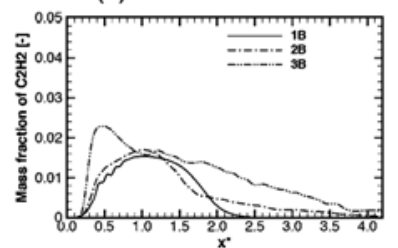

(c) Mass fraction of $\mathrm{C}_{2} \mathrm{H}_{2}$

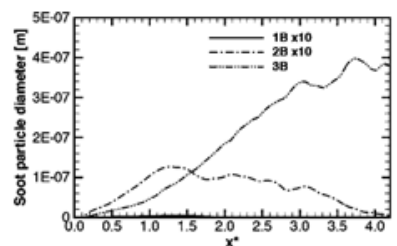

(b) Soot particle diameter

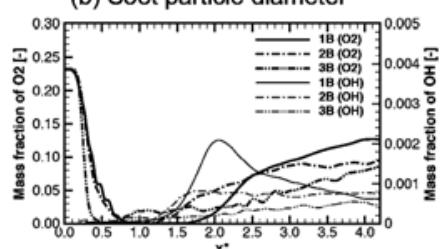

(d) Mass fractions of $\mathrm{O}_{2}$ and $\mathrm{OH}$
Fig. 9 Axial distributions of time-averaged soot volume fraction, soot particle diameter and mass fractions of $\mathrm{C}_{2} \mathrm{H}_{2}, \mathrm{O}_{2}$ and $\mathrm{OH}$ for $d_{p}=$ $25 \mu \mathrm{m}$.

に高い值を示すことがわかる。これは、より大きな油滴径 粒子の方が蒸発速度が遅いことにより、局所的に燃料ガス 過濃領域が形成されやすいことによるものと考えられる。

すす生成のメカニズムとそれに対する圧力の影響をより 定量的に調べるため、Fig. 9 に、 $d_{p}=25 \mu \mathrm{m}$ 時における中心 軸上の時間平均 (a) すす濃度、(b) すす粒径、(c) アセチレン 濃度、および (d) すすの酸化剂濃度（酸素と $\mathrm{OH}$ ラジカル) の分布を示す。図中 (a) のすす濃度分布からも、Fig. 6 ～ 8 において観察されたように圧力が高くなるに従い、すす濃 度は劇的に増加することがわかる。また、圧力の比較的低 い Case 1B と Case 2B では、 $x^{*}=1.0 \sim 1.5$ 付近にピーク值 をもつ一方で、圧力の高い Case 3B では、 $x^{*}=3.0$ 付近にピー ク值がもつことがわかる。これらの傾向は、図中 (b) のす す粒径分布からも読み取ることができる。すなわち、圧力 が高くなるに従い、すす粒径は大きくなる。また、すす粒 径のピーク值は、圧力の比較的低い Case 1B と Case 2B では、 $x^{*}=1.0 \sim 1.5$ 付近に現れる一方、圧力の高い Case 3B では、 中心軸上をほぼ単調に増加することがわかる。

これらの挙動を理解するために、すす前駆体と酸化剂で あるアセチレン、酸素、および $\mathrm{OH}$ ラジカルについて、注 目すると、アセチレンは混合分率との相関が強く、ピーク 值は上流域に現れること、また、下流に向かうに従い、徐々 に低下していくことがわかる。また、圧力が高くなるに従 い、アセチレン濃度のピーク值は高い值を示すとともに、 最も圧力の高い Case 3B では、下流域における濃度もより 高い值を示す。一方、すすの酸化刘である酸素は、温度分 布において着火後にピーク值をとる位置で最小值をとり、 その後下流に向かって徐々に上昇していく。OH ラジカル については、Case 1Bにおいて $x^{*}=2.0$ 付近にピーク值が現 れるものの、その他の条件では、下流に向かって徐々に増 加する傾向を示す。これは、下流域では、大規模な渦構造 
の発達に伴い、中心軸上にも外部流の酸素が巻き込まれる こと、この酸素の巻き込みに伴い、渦の内部や外縁に高温 領域が現れることによる。下流域における酸化剤濃度は、 圧力が低い条件ほど高い值を示しており、圧力が低い条件 の下流域において、すす濃度やすす粒径が減少する傾向に 符合する。

さらに詳しくすす生成に関与する反応を調べるため、 Fig. 10 に、 $d_{p}=25 \mu \mathrm{m}$ 時における中心軸上の時間平均す す生成・消費速度 ((a)Case 1B、(b)Case 2B、および (c)Case 3B)の分布を示す。ただし、Inc.は核生成速度を、Sur. は 表面成長速度を、Oxi.は酸化速度を、Coa.は凝集速度を、 Sum. はこれらの生成・消費速度の合計を表す。また、判別 のため、核生成速度と凝集速度については、縦軸を 100 倍 に拡大した。図中 (a)のCase 1Bにおいて、核生成速度の 高い領域は、アセチレン濃度の高い領域に対応しているこ とがわかる。また、核生成速度の分布形状は、凝集速度の 分布形状に一致しており、核生成と同時に凝集が進んでい ると推察される。表面成長速度は、 $x^{*}=1.4 \sim 1.5$ 付近で ピーク值をとり、この表面成長反応がすす生成を支配して いることが分かる。一方、酸化反応が顕著になるのは、 $x^{*}$ $=1.6 \sim 1.7$ 付近であり、表面成長反応が顕著な領域よりも 若干下流に位置するため、 $x^{*}=1.6 \sim 2.0$ の領域では、すす の生成反応よりも酸化による消費反応の方が顕著であるこ とがわかる。圧力の影響について注目すると、圧力が高く なるに従い、すす生成反応と消費反応はともに高くなる傾 向を示すことがわかる。また、各圧力条件において、すす 生成に対して表面成長反応が支配的であることは同様であ るが、表面成長速度がピーク值をもつ位置は、圧力が高く なるに従い、下流に移動する。さらに、比較的圧力の低い Case 1B と Case 2B では、すす生成・消費反応領域の下流 域に、生成反応よりも消費反応の方が顕著となる領域をも つ一方で、最も圧力の高い Case 3B では、消費反応が生成 反応を上回ることはない。これは、圧力が高くなるに従い、 すす濃度やすす粒径のピーク值が下流域に移動する傾向に 符号する。

\section{4. 結 論}

本研究では、 $n$-デカンの噴流噴霧火炎に対して、2 次元 DNS を実施することにより、すす生成挙動に及ぼす圧力の 影響について検討を行った。得られた主な知見は以下の通 りであった。

1）噴流噴霧火炎において、すすは、主として、噴流の下流 域に発達する渦状火炎内部において生成される。これは、 渦状火炎の内部は、高温かつ酸化剂不足な状態にあり、 上流域で生成されたすすの核粒子が、表面成長や凝集に より成長するための十分な滞留時間があることによる。 また、すす生成反応で支配的なのは表面成長反応である。 2) 圧力が高くなるに従い、噴流の下流域に発達する渦状火

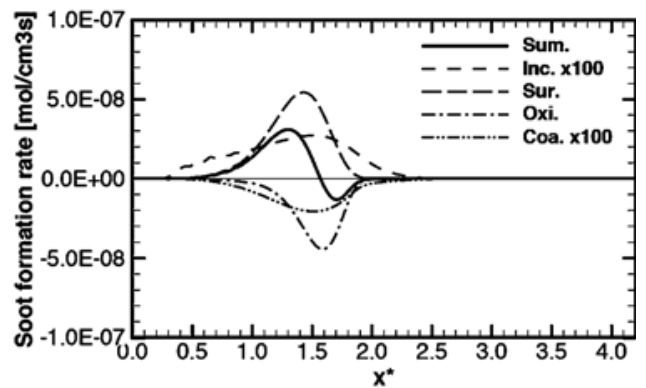

(a) Pressure $=0.1[\mathrm{MPa}]$

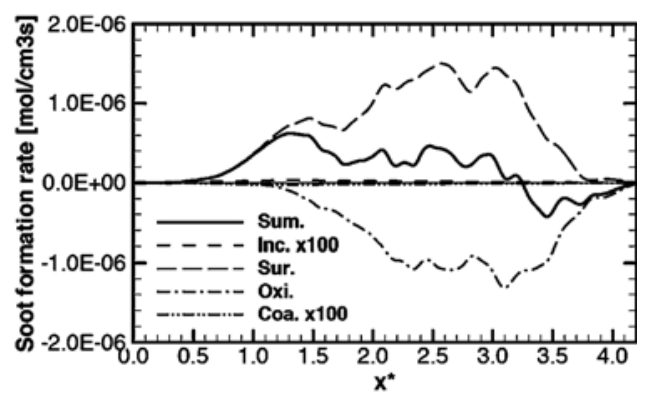

(b) Pressure $=0.2[\mathrm{MPa}]$

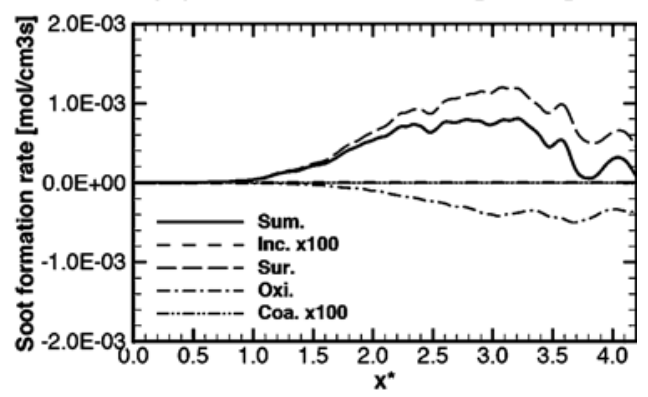

(c) Pressure $=0.5[\mathrm{MPa}]$

Fig. 10 Axial distributions of time-averaged soot formation rate for $d_{p}=$ $25 \mu \mathrm{m}$.

炎の構造は微細化するとももに、より上流から発達をす る。圧力の上昇とともに、すすの濃度や粒径は高い值を 示す。これは、圧力が高くなると、すす前駆体であるア セチレン濃度のピーク值が高くなることや、渦状火炎構 造が微細化することで、相対的にすす粒子が表面成長や 凝集により成長するための滞留時間が長くなることによ るものと考えられる。

\section{謝 辞}

本研究の一部は文部科学省高性能汎用計算機高度利用事 業「HPCI 戦略プログラム（研究分野 4 次世代ものづくり）」 の補助を受けて実施された。ここに記して、謝意を表する。

\section{参考文献}

1) R. Kurose, O. Desjardins, M. Nakamura, F. Akamatsu and H. Pitsch: CTR Annual Research Briefs - 2004, Center for Turbulence 
Research, NASA Ames/Stanford Univ., (2004) 269-280.

2) M. Nakamura, F. Akamatsu, R. Kurose and M. Katsuki: Phys. Fluids, 17 (2005) 123301.

3) H. Watanabe, R. Kurose, S.-M. Hwang and F. Akamatsu: Combust. Flame, 148 (2007) 234-248.

4) Y. Baba and R. Kurose: J. Fluid Mech, 612 (2008) 45-79.

5) R. Kurose and F. Akamatsu: J. Combust. Soc. Japan, 50 (2008) 206214.

6) M. Frenklach and S. Harris: J. Coll. Interf. Sci., 118 (1987) 252-261.

7) S. Brookes and J. Moss: Combust. Flame, 116 (1999) 486-503.

8) H. Pitsch, E. Riesmeier and N. Peters: Combust. Sci. Technol., 158 (2000) 389-406.

9) Z. Wen, S. Yun, M. Thomson and M. Lightstone: Combust. Flame, 135 (2003) 323-340.

10) H. El-Asrag, T. Lu, C. Law and S. Menon: Combust. Flame, 150 (2007) 108-126.

11) H. Watanabe, R. Kurose, S. Komori and H. Pitsch: Combust. Flame, 152 (2008) 2-13.

12) H. Watanabe, R. Kurose, H. Makino and S. Komori: J. Soc. Powder Technol. Japan, 46 (2009) 22-31.

13) J. Hayashi, H. Watanabe, R. Kurose and F. Akamatsu: Combust. Flame, 158 (2011) 2559-2568.

14) H. Watanabe, R. Kurose, Y. Yano, H. Makino and S. Komori: J. Soc. Powder Technol. Japan, 49 (2012) 467-477.

15) M. Mueller and H. Pitsch: Combust. Flame, 159 (2012) 2166-2180.

16) H. Pitsch and H. Steiner, Phys. Fluids, 12 (2000) 2541-2554.

17) C. Pierce and P. Moin: J. Fluid Mech., 504 (2004) 73-97.

18) L. Selle, G. Lartique, T. Poinsot, R. Koch, K.-U. Schildmacher, W. Krebs, P. Kaufmann and D. Veynante: Combust. Flame, 137 (2004) 489-505.
19) N. Peters: Prog. Energy Combust. Sci., 10 (1984) 319-339.

20) M. Ihme and H. Pitsch: Phys. Fluids, 20 (2008) 055110.

21) R. Kurose and S. Komori: J. Fluid Mech., 384 (1999) 183-206.

22) F. Ham, S. Apte, G. Iaccarino, X. Wu, M. Hermann, G. Constantinescu, K. Mahesh and P. Moin: CTR Annual Research Briefs-2003, Center for Turbulence Research, NASA Ames/Stanford Univ., (2003) 139-160.

23) R. S. Miller and J. Bellan: J. Fluid Mech., 384 (1999) 293-338.

24) R. Kurose, H. Makino, S. Komori, M. Nakamura, F. Akamatsu and M. Katsuki: Phys. Fluids, 15 (2003) 2338-2351.

25) A. Fujita, H. Watanabe, R. Kurose and S. Komori: Fuel, submitted.

26) G. Bikas and N. Peters: Combust. Flame, 126 (2001) 1456-1475.

27) K. M. Leung, R. P. Lindstedt and W. P. Jones: Combust. Flame, 87 (1991) 289-305.

28) U. Vandsburger, I. Kennedy and I. Glassman: Combust. Sci. Technol., 39 (1984) 263-285.

29) R. Puri, T. F. Richardson, R. J. Santoro and R. A. Dobbins: Combust. Flame, 92 (1993) 320-333.

30) M. Frenklach, D. W. Clary, J. Gardiner and S. E. Stein: Proc. Combust. Inst., 20 (1984) 887-901.

31) S. J. Harris, A. M. Weiner and R. J. Blint: Combust. Flame, 72 (1988) 91-109.

32) P. R. Lindstedt: Soot Formation in Combustion, Mechanisms and Models, Springer-Verlag, Berlin, (1994) 417-441.

33) Y. Morinishi, T. S. Lund, O. V. Vasilyev and P. Moin: J. Compu. Phys., 143 (1998) 90-124.

34) A. Leonard: Compu. Meth. Appl. Mech. Eng., 19 (1979) 15-98.

35) J. Kim and P. Moin: J. Compu. Phys., 59 (1985) 308-323.

36) J. Sato, M. Tsue, M. Niwa and M. Kono: Combust. Flame, 82 (1990) 142-150. 